\title{
Potential Entrepreneurs' Assessment of OpPortunities Through the Rendering of a Business Plan
}

\author{
Melodi Botha and Claire Leanne Robertson \\ Department of Business Management, University of Pretoria
}

Accepted: August 2013

\begin{abstract}
In the field of entrepreneurship and especially during start up, much emphasis is placed on the business plan with regard to entrepreneurship education and training, funding from external investors, business plan competitions and government development agencies in the Small, Medium and Micro Enterprise (SMME) sector. In many earlier studies of well-known entrepreneurship educators, the formulation of a business plan was identified as being the most important feature of any entrepreneurship programme or course. However, the relevance of a business plan has been a topic of intense and unresolved debates in more recent literature. This paper contributes to the literature with regard to the value a business plan adds to potential entrepreneurs. Furthermore it increases the understanding of how a detailed business plan (such as the approved business plan template of the University of Pretoria) can enable a potential entrepreneur to assess opportunities. The paper conducts a comprehensive analysis of business plans and the methods of assessing opportunities, in order to reveal similarities between the business plan and opportunity assessment. Based on descriptive statistics and inferential statistics such as ANOVA, and Kruskal-Wallis tests, the findings support the hypotheses that potential entrepreneurs distinguish between ideas and opportunities and develop opportunities through the formulation of a detailed business plan. The pertinent academic and practical significance of this paper is that it highlights statistically significant differences proving that a detailed business plan is a tool that enables potential entrepreneurs to assess opportunities. From a practical point of view, this should help potential entrepreneurs to establish more viable business ventures; however, this would have to be statistically tested in further research. Finally, the study reestablishes the importance and purpose of a business plan in the field of entrepreneurship.
\end{abstract}

Key words: potential entrepreneurs, business plan and opportunity assessment

JEL: L26

1

\section{Introduction and research question}

Globally, governments spend enormous amounts of money on entrepreneurship education, coaching facilities and mentorship programmes in the SMME sector. The reason for this is that entrepreneurs act as engines of growth in the economy (Venkataraman, 1997:119; Ketchen, 2003:281; McMullen, 2011:185). Business plans are seen as the most central evaluation and educational tool in governmental support for new business ventures (Karlsson \& Honig, 2009:28). Thus a very dominant product offering, in not only all governmental institutions but also in privately owned developmental institutions, is the business plan, or assistance in the preparation of the business plan. However, compiling a business plan is often an expensive and time-consuming task (Wickham, 2006:375). The time and resources that are spent by entrepreneurs who write their own business plans could have arguably been spent on other useful activities, such as obtaining new customers, or establishing good supplier relationships (Ashamalla, Orife, \& Abel, 2008:383; Karlsson \& Honig, 2009:28). Smeltzer, Van Hook and Hutt (1991:10) state that the business plan is difficult to prepare, requiring the entrepreneur to analyse all aspects of the venture.

Barrow, Barrow and Brown (2001:6) note that perhaps the most important step in launching any new venture or expanding an existing one is the construction of a business plan. There are many authors who either agree or disagree with this statement. The debate surrounding the value of the business plan is 
evident in all relevant new business creation and entrepreneurship literature. The actual reason for the validity of the business plan is unclear. Is it because of the increased performance results, its ability to help the entrepreneur to obtain loans or to reduce risk? Or is it something else entirely? Numerous books and articles in the popular press attempt to dissect and analyse the business plan, while simultaneously a growing number of annual business plan contests are evident in many countries (Lange, Mollov, Pearlmutter, Singh \& Bygrave, 2007:237), and both graduate and undergraduate schools devote entire courses to the subject (Honig, 2004:258). The University of Pretoria (UP) teaches the business plan as a subject on second year (undergraduate) and Masters' (postgraduate) levels.

Determining the value or importance of the business plan is imperative for the benefit of entrepreneurs, educators in entrepreneurship, researchers of entrepreneurship and government agencies involved in the development of entrepreneurship in the SMME sector. Many different authors believe that the most important step in launching any new business or expanding an existing one is the development of a business plan (Barrow et al., 2001:6). They emphasise that a business plan serves the purpose of defining the venture and explaining how it will operate in the marketplace (Hormozi, Sutton, McMinn \& Lucio, 2002:755). A business plan provides not only internal benefits, but also has external functions (Ashamalla et al., 2008:381). Shane and Delmar (2004:782) demonstrated that completing business plans before undertaking marketing activities reduced the potential of termination of new ventures. These authors argue that the benefits of planning before action exceed the opportunity cost on the entrepreneur's time (Kickul, Gundry, Barbosa, \& Whitcanack, 2009:439). Ashamalla et al. (2008:386) asked the question; “Are business plans a relic of the past, by asking a sample if they would agree with this statement: "Bum your business plan?" Only less than 5 per cent of the respondents agreed with the notion that business plans should be burnt (indicating that it is a relic of the past). Over 95 per cent disagreed, reflecting the thinking that business plans are still relevant today.

Based on the above discussion, it then put forward a hypothesised reason for the importance of the business plan, supported by more contemporary literature, aiming to determine the value of the business plan and justify the time, money and opportunity costs spent by entrepreneurs on formulating such a plan. The theoretically supported and statistically untested purpose of formulating a business plan is hypothesised to be opportunity assess mention (refer to Figure 1). Thus the main aim of the paper is to provide evidence that by formulating a business plan potential entrepreneurs can assess opportunities. Assessing opportunities encompasses two primary tasks: (a) distinguishing between an idea and opportunity; and (b) developing the opportunity. For the purpose of this paper, a potential entrepreneur is one who does not have a business yet but is in the process of gathering resources to start a business. The research question posed in this paper is as follows: Does formulating a business plan enable potential entrepreneurs to assess opportunities by (a) distinguishing between ideas and opportunities, and (b) developing their opportunities? The research question was filtered directly into the subsequent objectives and hypotheses, which are statistically tested.

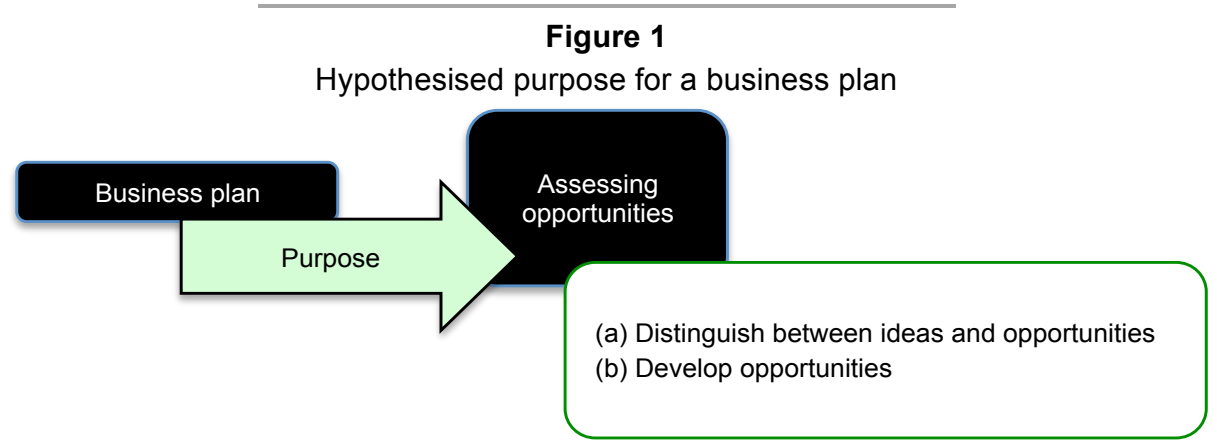


2

\section{Literature review}

\subsection{The value of a business plan}

The business plan is a generally well-known document. Despite much emphasis being placed on business plans in the entrepreneurship field, there is still much discussion about the success of this tool to add value to entrepreneurs or their business ventures. The heated discussions emanate from the different purposes associated with the business plan as well as the uncertainty of the outcomes. A full understanding of past and present discussions is required in order to substantiate the theoretically supported and statistically untested purpose for the business plan: assessing opportunities.

The comprehensive analysis of the business plan revealed a variety of available business plan definitions, which is a possible explanation of the non-commensurability of the business plan literature as well as the business plan content. The definition of the business plan for the purpose of this study is: "A business plan carefully articulates the merits, requirements, risks and potential rewards of the opportunity and how it is seized" (Timmons \& Spinelli, 2007:223). It is also imperative to note that the UP-approved business plan framework, which is a more detailed business plan framework, is suggested as the necessary business plan structure for the study's investigation of opportunity assessmention. The business plan structure from the University of Pretoria was converged from the top 12 business plans from financial institutions such as commercial banks, angel investors and venture capitalists in July 2006 by Sasol ChemCity and the UP (Botha \& Bouwmeesters, 2006:1).

Appendix 1 illustrates the UP's business plan framework (Botha \& Bouwmeesters, 2006: 1 ), and the authors whose literature corresponds to specific content.

\subsection{Types of business plans}

There are different types of business plans depending on the purpose. Different circumstances will require different types of business plans. Depending on the type of business plan, certain sections will be emphasised, as some information will be more important for certain circumstances or purposes. The purpose of a business plan can be multifaceted; however, it has been stated (Struwig, 2009:104) that a business plan has three primary purposes: (1) to serve an internal purpose for the business (one of the main objectives being planning), (2) to obtain funding, and (3) to be used as a tool for reducing risk. A purpose that has not been mentioned as a primary purpose is survival or success. A possible reason for this is that survival or success emanates from the three primary purposes; that is, as a result of obtaining funding, internal planning or reducing risk in the business, the venture is able to survive or succeed. The literature either agrees, agrees somewhat or disagrees. Inconsistency in research results may have been due to an inconsistency in business plan definition, content or formulation.

\subsection{Assessing ideas, opportunities and business plans}

Not all literature distinguishes between ideas and opportunities (Wickham, 2006:235). Perhaps the authors are unaware of the distinctive nature of these concepts, or else they disagree with distinguishing between the two concepts. There are some authors who allude to the distinction but do not state it clearly (Hisrich, Peters \& Shepherd, 2008:152). However, there are numerous authors who do distinguish between the two concepts (Nieman \& Nieuwenhuizen, 2009:86; Timmons \& Spinelli, $2007: 118$ ), primarily in the field of entrepreneurship. This paper concurs with the latter group of authors. In fact, the distinction between these two concepts, ideas and opportunities, is significant to this study. Ideas, for the purpose of this study, are defined as a combination of the following: "A necessary but not sufficient condition for business opportunities to emerge" (Dimov, 2007:718), and "Not a feasible and viable business opportunity" (Nieman \& Nieuwenhuizen, 2009: $85)$. Business or entrepreneurial opportunities, for the purpose of the study, are defined as the following: "A potentially feasible, profitseeking business that offers a new product/ service to the market, improves an alreadyexisting product/service or imitates a profitable 
product/service in a non-saturated market" (Singh, 2001:10-12).

Evaluation is key to differentiating an idea from an opportunity (Hills \& Shrader, 1998: 32). This study distinguishes two primary tasks included in opportunity assessment, resulting from two dominant definitions found through an analysis of the business opportunity literature: (a) distinguishing opportunities from ideas (Krueger, 1993:5; Krueger \& Brazeal, 1994:91; Krueger, 2000:5; Keh, Foo \& Lim, 2002:125), and (b) developing opportunities (Ardichvili, Cardozo \& Ray, 2003:113; Dimov, 2007:714). These two tasks may take place simultaneously or in random order.

The literature review concludes with opportunity assessment criteria and the similarities found to the UP business plan criteria. Table 1 reflects the comparison between the UP business plan content and opportunity assessment criteria). One opportunity assessment, as presented in Table 1, stood out from the rest, as it was the most extensive. This opportunity evaluation is presented by Timmons and Spinelli (2007: 128) and supported by Nieman and Nieuwenhuizen
(2009:87). Table 1 demonstrates the corresponding information needed to assess an opportunity accurately and the information needed to be gathered and interpreted to formulate a business plan. However, Timmons and Spinelli (2007:228) suggest that there are differences between the business plan and the opportunity assessment. They state that the business plan needs to contain more detail and strategies and this was also adopted in the UP business plan framework. It is stated that the opportunity assessment is the foundation for the business plan. Nonetheless, the extensive overlap cannot be ignored. Approximately 90 per cent of information required to assess opportunities corresponds with information that is required in the business plan, which in both instances would need to be researched, gathered and processed by the potential entrepreneur.

Thus this study was conducted to establish whether potential entrepreneurs assess opportunities through the formulation of a detailed business plan such as the UP business plan (Botha \& Bouwmeesters, 2006:1).

Table 1

Corresponding information found in a business plan and the assessment of an opportunity

\begin{tabular}{|c|c|c|}
\hline Opportunity assessment content & $\begin{array}{c}\text { UP approved business plan content/detailed } \\
\text { business plan (refer to Appendix 1) }\end{array}$ & Degree of correspondence \\
\hline $\begin{array}{l}\text { (1) Industry and market } \\
\text { Market needs } \\
\text { Customers } \\
\text { User benefits } \\
\text { Value added } \\
\text { Product life } \\
\text { Market structure } \\
\text { Market size } \\
\text { Growth rate } \\
\text { Market capacity } \\
\text { Market share attainable } \\
\text { Cost structure }\end{array}$ & $\begin{array}{l}\text { *Industry analysis and market research } \\
\text { Corresponds (information also required in the } \\
\text { business plan) } \\
\text { Corresponds } \\
\text { Corresponds } \\
\text { Corresponds } \\
\text { Corresponds } \\
\text { Corresponds } \\
\text { Corresponds } \\
\text { Corresponds } \\
\text { Corresponds } \\
\text { Corresponds } \\
\text { Corresponds }\end{array}$ & $\begin{array}{l}100 \% \text { of the information } \\
\text { required to assess an } \\
\text { opportunity is also required to } \\
\text { formulate the business plan }\end{array}$ \\
\hline $\begin{array}{l}\text { (2) Economics of the business } \\
\text { Profit after tax } \\
\text { ROI potential } \\
\text { Capital requirements } \\
\text { Internal rate of return potential } \\
\text { Free cash flow characteristics } \\
\text { Sales growth } \\
\text { Asset intensity } \\
\text { Spontaneous working capital } \\
\text { R\&D/ capital expenditure } \\
\text { Gross margins } \\
\text { Time to Break-even - cash flow and profit }\end{array}$ & $\begin{array}{l}{ }^{*} \text { Economics of the business } \\
\text { Corresponds } \\
\text { Corresponds } \\
\text { Corresponds } \\
\text { Corresponds } \\
\text { Corresponds } \\
\text { Corresponds } \\
\text { Corresponds } \\
\text { Corresponds } \\
\text { Corresponds }\end{array}$ & $\begin{array}{l}82 \% \text { of the information } \\
\text { required to assess an } \\
\text { opportunity is also required to } \\
\text { formulate the business plan }\end{array}$ \\
\hline
\end{tabular}




\begin{tabular}{|c|c|c|}
\hline Opportunity assessment content & $\begin{array}{c}\text { UP approved business plan content/detailed } \\
\text { business plan (refer to Appendix 1) }\end{array}$ & Degree of correspondence \\
\hline $\begin{array}{l}\text { (3) Harvest issues } \\
\text { Value-added potential } \\
\text { Valuation multiple and comparables } \\
\text { Exit mechanism and strategy } \\
\text { Capital market context }\end{array}$ & $\begin{array}{l}\text { *Growth plan } \\
\text { Corresponds } \\
\text { Corresponds }\end{array}$ & $\begin{array}{l}50 \% \text { of the information } \\
\text { required to assess an } \\
\text { opportunity is also required to } \\
\text { formulate the business plan }\end{array}$ \\
\hline $\begin{array}{l}\text { (4) Competitive advantages issues } \\
\text { Fixed and variable costs } \\
\text { Control over costs, prices, and distribution } \\
\text { Barriers to entry } \\
\text { Proprietary protection } \\
\text { Response/lead times } \\
\text { Legal, contractual advantage } \\
\text { Contacts and networking } \\
\text { Key people }\end{array}$ & $\begin{array}{l}{ }^{*} \text { Market analysis } \\
\text { Corresponds } \\
\text { Corresponds } \\
\text { Corresponds } \\
\text { Corresponds } \\
\text { Corresponds } \\
\text { Corresponds } \\
\text { Corresponds } \\
\text { Corresponds }\end{array}$ & $\begin{array}{l}100 \% \text { of the information } \\
\text { required to assess an } \\
\text { opportunity is also required to } \\
\text { formulate the business plan }\end{array}$ \\
\hline (5) Fatal-flaw issues & $\begin{array}{l}\text { *Critical risks, problems and assumptions } \\
\text { Corresponds }\end{array}$ & $\begin{array}{l}100 \% \text { of the information } \\
\text { required to assess an } \\
\text { opportunity is also required to } \\
\text { formulate the business plan }\end{array}$ \\
\hline $\begin{array}{l}\text { (6) Management team } \\
\text { Entrepreneurial team } \\
\text { Industry and technical experience } \\
\text { Integrity } \\
\text { Intellectual honesty }\end{array}$ & $\begin{array}{l}\text { *Management team } \\
\text { Corresponds } \\
\text { Corresponds } \\
\text { Corresponds } \\
\text { Corresponds }\end{array}$ & $\begin{array}{l}100 \% \text { of the information } \\
\text { required to assess an } \\
\text { opportunity is also required to } \\
\text { formulate the business plan }\end{array}$ \\
\hline $\begin{array}{l}\text { (7) Personal criteria } \\
\text { Goals and fit } \\
\text { Upside/downside issues } \\
\text { Opportunity costs } \\
\text { Desirability } \\
\text { Risk/rewards tolerance } \\
\text { Stress tolerance }\end{array}$ & $\begin{array}{l}\text { Corresponds } \\
\text { Corresponds } \\
\text { Corresponds } \\
\text { Corresponds } \\
\text { Corresponds } \\
\text { Corresponds } \\
\text { Corresponds }\end{array}$ & $\begin{array}{l}100 \% \text { of the information } \\
\text { required to assess an } \\
\text { opportunity is also required to } \\
\text { formulate the business plan }\end{array}$ \\
\hline $\begin{array}{l}\text { (8) Strategic differentiation } \\
\text { Degree of fit } \\
\text { Team } \\
\text { Service management } \\
\text { Timing } \\
\text { Technology } \\
\text { Flexibility } \\
\text { Opportunity orientation } \\
\text { Pricing } \\
\text { Distribution channels } \\
\text { Room for error }\end{array}$ & $\begin{array}{l}\text { "Business description } \\
\text { Corresponds } \\
\text { Corresponds } \\
\text { Corresponds } \\
\text { Corresponds } \\
\text { Corresponds } \\
\text { Corresponds } \\
\text { Corresponds } \\
\text { Corresponds } \\
\text { Corresponds } \\
\text { Corresponds }\end{array}$ & $\begin{array}{l}100 \% \text { of the information } \\
\text { required to assess an } \\
\text { opportunity is also required to } \\
\text { formulate the business plan }\end{array}$ \\
\hline
\end{tabular}

There are hundreds of examples of what the business plan should constitute. This paper now compares the content (business plan framework) of business plans from leading development institutions, software programmes and textbooks, to the content of the UP's business plan, presented in the above table. Australia's business plan (for immigrants acquiring a 'Business Talent Visa'), Business Plan Pro-Writer, and Business Partners' business plan are all reputable in the entrepreneurship field. Morrisette and Hatfield (2010:125) state that the "canned" structure of the business plan taken from Jeffrey Timmon's text, is also excellent.

From analysing the information shown in the tables above, it is concluded that the UP business plan framework is indeed an effective and detailed business plan structure and is a good framework and foundation to follow. However, the entrepreneur must remember that the amount of detail and the order in which information is presented can vary for each particular situation and will depend upon the purpose of the plan and the age and stage of the business venture, among other factors (Timmons \& Spinelli, 2007:229). 
Table 2

Business plan comparisons

\begin{tabular}{|c|c|c|c|c|c|}
\hline $\begin{array}{l}\text { Business } \\
\text { plans }\end{array}$ & $\begin{array}{l}\text { UP guidelines } \\
\text { for business } \\
\text { plan content }\end{array}$ & $\begin{array}{c}\text { Australian } \\
\text { business plan } \\
\text { content } \\
\text { (business.gov.au) }\end{array}$ & $\begin{array}{l}\text { Business plan Pro } \\
\text { writer programme } \\
\text { content (software) }\end{array}$ & $\begin{array}{c}\text { Business Partners' } \\
\text { business plan } \\
\text { content (SME } \\
\text { toolkit) }\end{array}$ & $\begin{array}{c}\text { Timmons business } \\
\text { plan content (text } \\
\text { book) }\end{array}$ \\
\hline $\begin{array}{l}\text { Content } \\
\text { similarity }\end{array}$ & \multirow{3}{*}{$\begin{array}{l}\text { Refer to Table } 1 \\
\text { for the } \\
\text { comparative } \\
\text { content }\end{array}$} & $\begin{array}{c}95 \% \\
\text { correspondence }\end{array}$ & $\begin{array}{c}80 \% \\
\text { correspondence }\end{array}$ & $\begin{array}{c}90 \% \\
\text { correspondence }\end{array}$ & $\begin{array}{c}100 \% \\
\text { correspondence }\end{array}$ \\
\hline $\begin{array}{l}\text { Additional } \\
\text { information }\end{array}$ & & - & - & - & - \\
\hline $\begin{array}{l}\text { Omitted } \\
\text { information that } \\
\text { was included in } \\
\text { the UP } \\
\text { business plan }\end{array}$ & & $\begin{array}{l}\text { Proposed business } \\
\text { offering (desired } \\
\text { finance) }\end{array}$ & $\begin{array}{l}\text { Action and growth } \\
\text { plans } \\
\text { Industry analysis } \\
\text { (macro analysis) } \\
\text { Proposed business } \\
\text { offering (desired } \\
\text { finance) }\end{array}$ & $\begin{array}{l}\text { Action plan } \\
\text { Proposed business } \\
\text { offering (desired } \\
\text { finance) }\end{array}$ & - \\
\hline
\end{tabular}

\subsection{The business plan for the purpose of assessing opportunities}

It is suggested (Timmons \& Spinelli, 2007:92; Ardichvilia, Cardozo \& Ray, 2003:109) that by addressing the types of questions necessary to shape the opportunity, the resources and the team, the founder begins to mould the idea into an opportunity, and the opportunity into a business plan. This paper postulates that the inverse is also true, by gathering and interpreting the information needed to formulate the business plan, one then has all the information in order to make a more accurate and informed decision of whether their idea is an opportunity. Furthermore the process of formulating the business plan (researching, gathering, and analysing information) allows for opportunity development/exploration. There are a few authors who have already alluded to the business plan's potential to assess opportunities. Delmar and Shane (2003:1165), include as part of business planning: the processes of gathering and analysing information, evaluating required tasks, identifying risks and strategy, projecting financial developments, and documenting these things in a written plan, in other words formulating a business plan. Wyckham and Wedley (1990:48) demonstrated the value of the business plan in distinguishing feasible ventures (opportunities) from unfeasible ventures (ideas).

The business plan itself is the culmination of a usually lengthy, arduous, creative, and iterative process that can transform a caterpillar (a raw idea) into a magnificent butterfly (an opportunity) (Timmons \& Spinelli, 2007:223). In writing and developing the business plan, the potential entrepreneur is forced to think about the various aspects of the business venture. This in itself means that information needs to be collected on all aspects of the opportunity and the resulting business venture (Nieman \& Nieuwenhuizen, 2009:22).

Pretorius (2008:14) states that a full opportunity analysis and assessment is a similar task to that undertaken for the start-up of a new venture, and core to the components of a business plan. Bishop and Nixon (2006:31) suggested that developing assessment decision aids might help improve potential entrepreneurs' evaluations, regardless of their experience levels. An evaluation tool would help entrepreneurs make more objective decisions regarding opportunity assessment. It could be argued that it might be difficult for entrepreneurs, especially for potential entrepreneurs, to just rely on cognitive ability to assess opportunities. Therefore a tool that could guide them would be most advantageous. This study postulates that the business plan, being so populous and similar to opportunity assessment, could be this tool.

"A good business plan must be developed in order to exploit the defined opportunity" (Hisrich et al., 2008:13). This study is in agreement with this statement but also postulates that the formulation of a business plan is even more important for the evaluation of business opportunities. The distinguishment between ideas and opportunities results from the gathering and interpreting of the required 
corresponding information for business plans and opportunity assessment. Figure 2 highlights that the development of opportunities through the formulation of a business plan, which allows a potential idea to be shaped, transformed, or improved into a business opportunity, is imperative to this study and will substantiate the value of a business plan for potential entrepreneurs. Thus a theoretically supported and statistically untested purpose for the formulation of a business plan is hypothesised, assessing opportunities.

\section{Figure 2}

A graphical illustration of the hypothesised purpose of the study

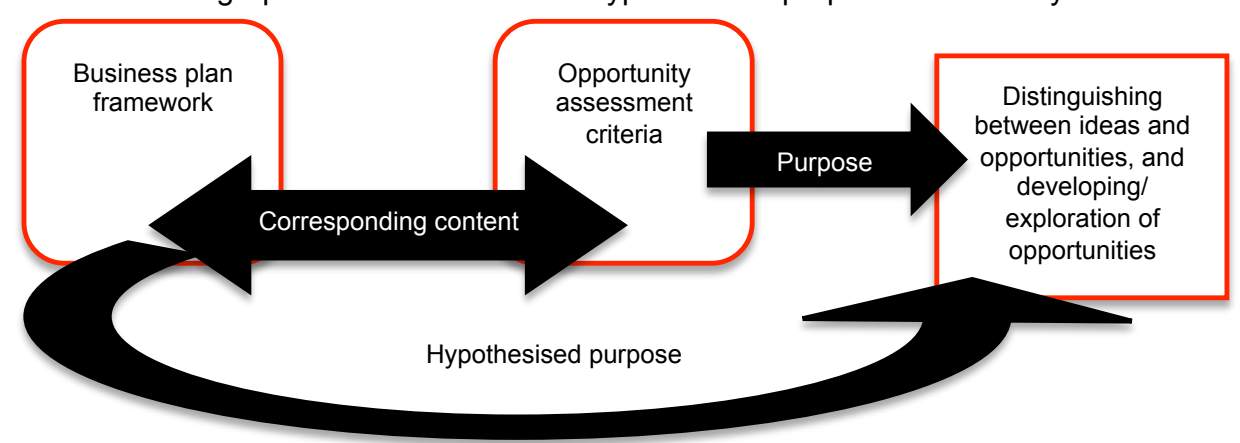

\section{3}

\section{Research design}

In this study, quantitative research is conducted. The purpose of this study is to ascertain through causal research whether there is a correlation or more specifically causality between the formulation of a business plan and the assessment of opportunities.

In this study, the business plan is the independent variable (IV), and assessment of opportunities the dependent variable (DV). Business ownership; when the business was started; education; and how the business plan was formulated were also added and included as independent variables (IVs). The study hypothesised the relationship of the above independent and dependent variables. The hypotheses stated in this study are explanatory (causal) hypotheses, as there was an implication that the existence of one or a change in one variable caused or led to a change in the other variable (Cooper \& Schindler, 2008:66).

Unfortunately, most research studies cannot be carried out experimentally by manipulating variables. However, one can still study subjects that have been exposed to the independent variable and those that have not, and compare the results (Cooper \& Schindler, $2008: 156)$. This is known as ex post facto design, which is used in this study. In the ex post facto design the research has to accept the world the way it is found; investigators have no control over the variables in the sense of being able to manipulate them (Cooper \& Schindler, 2008:143).

The study adopted the simple random sampling technique, which is a probability sampling procedure, and the questionnaire as the method for data collection, as information about past events is often available only through surveying or interviewing people who remember the events (Cooper \& Schindler, 2008:215). The questionnaire consists of the following main sections:

Section 1: solicits demographic and socioeconomic information about previous or current potential entrepreneurs such as gender, age, level of education, race, and business ownership status.

Section 2: addresses the different aspects regarding the business plan. It identifies how the business plan was formulated as well as the content detail of the business plan in accordance with the UP business plan.

Section 3: contains questions about opportunity assessment. Primarily the questions relate to identifying between ideas and opportunities and the development of opportunities. The funnel technique is utilised in this section. 
This study concluded that the online questionnaire would be the optimum method, due to the sampling required as well as the use of available resources. However, during the data collection period, an alternation method was added in order to increase the actual sample size. Questionnaires were handed out, via the random sampling method, to BCom and M Phil UP students in a controlled environment during their examinations. The questionnaire was administered to 260 sample units in the sample frame, selected through the sampling process (Figure 3 explains the sampling process and how data was collected). This study's sample frame included respondents from Absa Enterprise Development branches across South Africa, SoftstartBTI and Business Partners (incubators), and UP students who studied BCom (Entrepreneurship) or MPhil (Entrepreneurship and Small Business Management). Due to the nature of these institutions, the respondents were guaranteed to have been potential entrepreneurs at some point, regardless of their current entrepreneurial status.

The actual sample size was 76 , as 80 responses were successfully completed and returned, while four respondents had to be excluded from the study, as they did not have business plans. A pilot study was conducted on three respondents, a statistical analyst and academics in order to test the design of the questionnaire. This study's target population or research population is previous potential entrepreneurs or current potential entrepreneurs in South Africa that were new or inexperienced when they formulated their business plan.

The study uses descriptive and inferential statistics to analyse the data collected. Descriptive statistics are the elementary transformation of raw data, in a way that describes the basic characteristics such as the central tendency, variability and shape of the distributions. Frequency tables, cross-tabulations, bar graphs and pie graphs are utilised in order to illustrate the descriptive statistics. This study consists of 'more than 2' subsamples, which were independent, and the measurement scales included nominal, ordinal and interval scales. The following statistical tests are employed in the analysis of this study: Analysis of Variance (ANOVA) and Kruskal-Wallis tests. Factor analysis is utilised to confirm validity as well as reliability in the study. It is important to note that factor analysis was done on the two factors separately and that each factor had nine items therefore the sample size of 76 was sufficient and factor analysis could be carried out successfully.

Figure 3

Sampling process

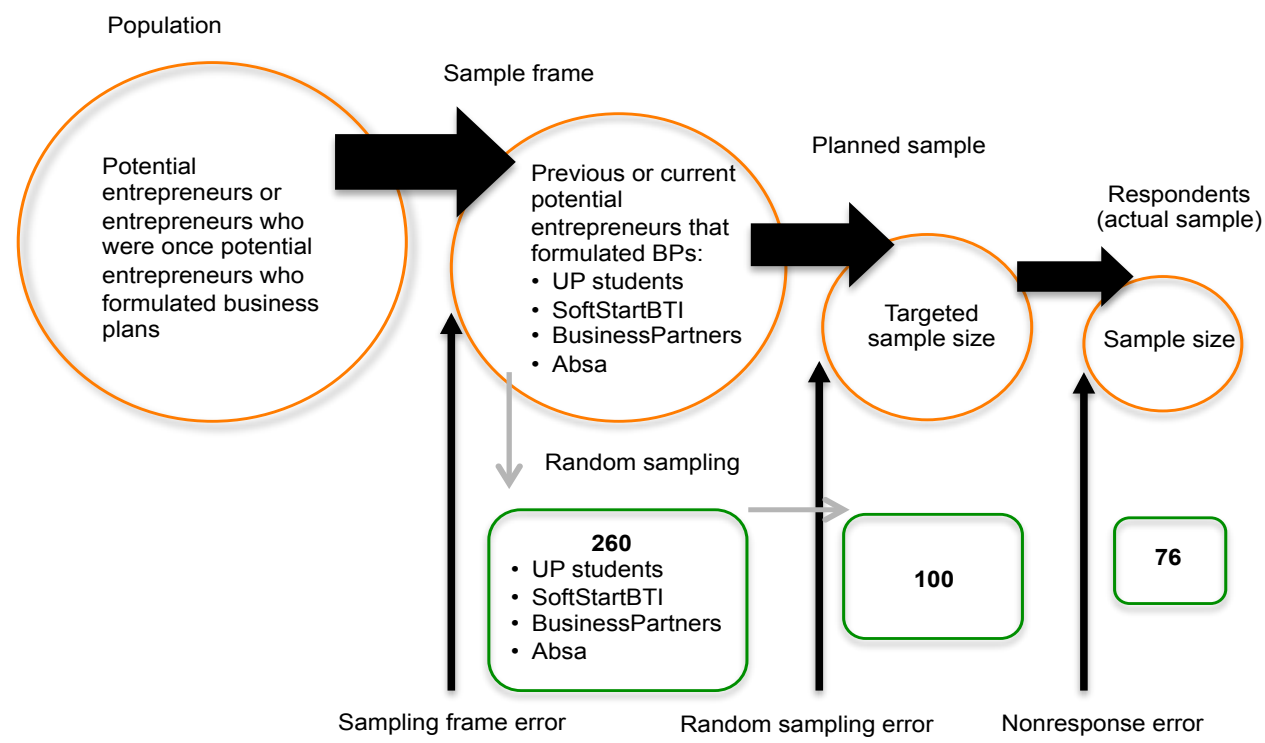




\subsection{Hypotheses testing}

The study performed hypotheses testing in order to accept or reject the null or alternative hypotheses. The three hypotheses developed are supported by the literature but they needed to be statistically tested and then either accepted or rejected, based on the findings and the levels of significance. If the probability of the occurrence of the observed data was smaller than the level of significance, then the data would suggest that the null hypothesis should be rejected.

Two types of errors can be committed in hypotheses testing, with the possibility of four situations. Under these situations, the null hypothesis could be either true or false and the decision to accept or reject the null hypothesis would emanate from a statistical decision. Type I error is rejecting a null hypothesis that should not be rejected, and a Type II error is not rejecting a null hypothesis that should be rejected (Diamantopoulos \& Schlegelmilch, 2000:138).

\section{4 \\ Empirical results}

\subsection{Demographics of the sample}

Out of the total sample (76 respondents), the male respondents represented 68.4 per cent (52 respondents), with the remaining 31.6 per cent (24 respondents) being female. The youngest age is 19 and the oldest age 68 . The average mean is 30.36 with a standard deviation of 11.66. The derived standard deviation of the age of respondents in this study, which is fairly high, represents a good assortment of ages. Regarding the respondents' education, the two categories with the most representation of respondents are Grade 12 learners, 34.2 per cent (26 respondents), and university postgraduates, 31.6 per cent (24 respondents), followed by university undergradduates, 17.1 per cent (13 respondents) and students from technikons, 7.9 per cent (7 respondents). This is a good distribution split between secondary and technikon, tertiary (university) and advanced tertiary (university) education.

\subsection{Data regarding business plans from the research sample}

This subsection identified what business plan template had been utilised by the sample. The results indicate that 46.1 per cent (35 respondents) of the sample used the UP business plan (Botha \& Bouwmeesters, 2006:1) template. This is an expected finding, due to the B. Com and M. Phil. Entrepreneurship students being included in the sample population. The percentage split allows for a comparison and statistical testing to be done between the UP business plan and the other business plans utilised. Respondents who used their own templates accounted for 15.8 per cent (12 respondents) of the total, followed by a consultants' template 10.5 per cent (12 respondents), other (combination of business plans) 9.2 per cent ( 7 respondents), internet and development agency's template, both 6.6 per cent (5 respondents each) and lastly no template, 5.3 per cent (4 respondents).

\subsection{Inferential statistics used to test the hypotheses}

This study's hypothesis 1 read as follows:

$\mathrm{H1}_{\mathrm{o}}$ : Potential entrepreneurs do not distinguish between ideas and opportunities through formulating a detailed business plan.

$\mathrm{H} 1_{\mathrm{a}}$ : Potential entrepreneurs distinguish between ideas and opportunities through formulating a detailed business plan.

Approximately 90 per cent of information required to assess opportunities corresponds with information that is required in the business plan, which in both instances would need to be researched, gathered and processed by the potential entrepreneur. This study distinguished two primary tasks included in opportunity assessment, resulting from two dominant definitions found through an analysis of the business opportunity literature. One of them was distinguishing opportunities from ideas (Krueger \& Brazeal, 1994:91; Krueger, 1993:5; Krueger, 2000:5; Keh et al., 2002:125).

The data regarding business plans from the research sample revealed a variety of business plan templates used, with detail ranging from very basic to very detailed. However, in each section in the business plan the highest count fell in the detailed or very detailed categories.

The data from the research sample regarding distinguishing between ideas and opportunities revealed that the majority of respondents strongly agreed or agreed with the statements presented to them in the questionnaire. The results indicated that 71.1 per cent 
to 85.5 per cent of respondents distinguished between ideas and opportunities when formulating their business plan.

Factor analysis (refer to Appendix 2) was done to establish the reliability and validity on the factor which was labelled as 'distinguishing between ideas and opportunities'. The Eigen value for this factor was 5.46590, and the factor explained 54 per cent of the variance in data. The Cronbach's alpha was 0.9146.

In order to employ ANOVA, two assumptions are required; (1) normal distribution of the residuals, and (2) equal variances. These assumptions were tested and the results showed that this was not the case. Therefore, a 'Normal Blom Transformation' was conducted, which then resulted in the assumptions been met and the study could continue with the running of ANOVA. Transformations are usually applied so that the data appear to more closely meet the assumptions of a statistical inference procedure that is to be applied. ANOVA was done to investigate the influence of the IV on the DV. It is important to note that ANOVA was done on the factor of which nine items measured the respondents' ability to distinguish between ideas and opportunities and on a question that directly asked the respondents to which degree they could distinguish between ideas and opportunities. In Table 3 it can be seen as Factor: distinguishing between ideas and opportunities and direct question. The first significant finding involved the variables 'business plan' and 'factor: distinguishing between ideas and opportunities'. The $p$-value was 0.0260 , thus the $p$-value $<$ 0.05 , which revealed that a real, significant difference was found. These results indicated that there was a statistically significant difference between the respondents' ability to distinguish between ideas and opportunities through the formulation of a business plan, depending of the different types of business plan templates used. Thus, respondents who used a UP business plan, which is guaranteed to be detailed, stated they distinguished more strongly between ideas and opportunities meaning that their scores where better than the respondents who used other templates. The means for the UP template used was 1.62, Development agencies and consultants' templates was 2.26 and own template, internet template, no template or other was 2.21. The second significant finding involved the variables 'business ownership' and the 'direct question'. The $p$-value was 0.0434 , thus the $p$-value $<$ 0.05 , which revealed that a real, significant difference was found. These results indicated that there was a statistically significant difference between the respondents' perception of their ability to distinguish between ideas and opportunities after formulating a business plan depending on their current business ownership status. Respondents that currently had businesses showed slightly higher confidence levels in their ability to distinguish between ideas and opportunities, compared with respondents who did not currently have businesses.

Table 3

ANOVA results

\begin{tabular}{|c|c|c|c|c|c|c|c|c|}
\hline \multicolumn{3}{|c|}{$\begin{array}{c}\text { Factor: } \\
\text { Distinguishing } \\
\text { between ideas and } \\
\text { opportunities }\end{array}$} & $\begin{array}{c}\text { Direct question: To what } \\
\text { degree did you know that } \\
\text { your business idea was a } \\
\text { business opportunity } \\
\text { after formulating your } \\
\text { business plan? }\end{array}$ & $\begin{array}{c}\text { Factor: Developing } \\
\text { opportunities }\end{array}$ & $\begin{array}{c}\text { Direct question: To what } \\
\text { degree did your original } \\
\text { business idea change or } \\
\text { improve during the } \\
\text { formulation of your } \\
\text { business plan? }\end{array}$ \\
\hline \multicolumn{1}{|c|}{ Variables } & F Value & Pr $>$ F & F Value & Pr > F & F Value & Pr > F & F Value & Pr $>$ F \\
\hline Business ownership & 0.37 & 0.5461 & 4.23 & $0.0434^{*}$ & 0.02 & 0.9027 & 0.13 & 0.7146 \\
\hline Business plan & 3.85 & $0.0260^{*}$ & 2.03 & 0.1392 & 3.03 & $0.0545^{\star *}$ & 0.23 & 0.7986 \\
\hline Education & 2.89 & 0.0620 & 0.36 & 0.7006 & 2.26 & 0.1119 & 0.35 & 0.7050 \\
\hline
\end{tabular}

* Statistically significant difference, $\alpha<0.05$ (95 per cent confidence level)

** Statistically significant difference, $\alpha<0.1$ (90 per cent confidence level)

Note: On the questionnaire the lowest score indicates the positive (strongly agree) and the highest score indicates the negative (strongly disagree).

The Kruskal-Wallis analysis (refer to Table 4) was done to compare the ability of respondents to distinguish between ideas and opportunities between the different types of entrepreneurs 
(potential, new or established). The $p$-value was 0.0401 , thus the $p$-value $<0.05$, which revealed that a real, significant difference was found. Current potential entrepreneurs that had not yet started their business but planned on starting their own business indicated more strongly that through the formulation of the business plan they could distinguish between ideas and opportunities. Note: On the questionnaire the lowest score indicates the positive (strongly agree) and the highest score indicates the negative (strongly disagree).

Table 3

Kruskal-Wallis test: The mean and $P$-values for when the respondents' business was started

\begin{tabular}{|c|c|c|c|c|}
\hline Year business was started & $\begin{array}{c}\text { 1986-2007 } \\
\text { (Currently } \\
\text { established } \\
\text { Entrepreneur) }\end{array}$ & $\begin{array}{c}\text { 2008-2011 } \\
\text { (Currently new } \\
\text { entrepreneur) }\end{array}$ & $\begin{array}{l}\text { Have not started a } \\
\text { business as yet } \\
\text { (Currently potential } \\
\text { entrepreneur) }\end{array}$ & P-value \\
\hline $\begin{array}{l}\text { Factor: Distinguish between ideas and } \\
\text { opportunities }\end{array}$ & $2.1333333^{a}$ & $2.1565657^{a}$ & $1.7058824 \mathrm{~b}$ & $0.0401^{*}$ \\
\hline Factor: Developing opportunities & $2.0777778^{a}$ & $1.9444444^{a}$ & $1.7222222^{\mathrm{a}}$ & 0.1004 \\
\hline
\end{tabular}

*Statistically significant difference, $\alpha<0.05$ (95 per cent confidence level)

*Means with different Superscripts differ significantly on a 0.05

Based on the tests conducted and the empirical results achieved, the null hypothesis was rejected and the alternative hypothesis was accepted.

This study's hypothesis 2 read as follows:

$\mathrm{H} 2_{\mathrm{o}}$ : Potential entrepreneurs do not develop opportunities through formulating a detailed business plan.

$\mathrm{H} 2_{\mathrm{a}}$ : Potential entrepreneurs develop opportunities through formulating a detailed business plan.

Approximately 90 per cent of the information required to assess opportunities corresponds with information that is required in the business plan, which in both instances would need to be researched, gathered and processed by the potential entrepreneur. This study distinguished two primary tasks included in opportunity assessment, resulting from two dominant definitions found through an analysis of the business opportunity literature. One of them was developing opportunities (Ardichvili et al., 2003:113; Dimov, 2007:714).

The data from the research sample regarding opportunity development revealed that the majority of respondents strongly agreed or agreed with the statements presented to them in the questionnaire. The results indicated that 72.4 per cent to 86.8 per cent of respondents developed opportunities when formulating their business plan.

Factor analysis (refer to Appendix 2) was done to establish the reliability and validity on the factor which was labelled as 'developing opportunities'. The Eigen value for this factor was 4.19933, and the factor explained 41 per cent of the variance in data. The Cronbach's alpha score was 0.8458 .

ANOVA was done to investigate the influence of the IV on the DV. It is important to note that ANOVA was done on the factor of which nine items measured the respondents' ability to develop opportunities and on a question that directly asked the respondents to which degree their business idea changed or improved during the formulation of their business plans. In Table 3 it can be seen as Factor: developing opportunities and direct question. The only significant finding involved the variables 'business plan' and 'factor: developing opportunities'. The $p$-value was 0.0545 , thus the $p$-value $<0.1$, which revealed that a significant difference was found. These results indicated that there was a statistically significant difference between the respondents' ability to develop opportunities through the formulation of a business plan depending on the type of business plan template used. Thus, respondents who used a UP business plan, which is guaranteed to be detailed, had better scores than the respondents who used other templates. The means for the UP template used was 1.66, Development agencies and consultants' templates were 2.01 and own template, internet template, no template or other was 2.09. 
Based on the tests conducted and the empirical results achieved, the null hypothesis was rejected and the alternative hypothesis was accepted.

This study distinguished two primary tasks included in opportunity assessment, resulting from two dominant definitions found through an analysis of the business opportunity literature; (a) distinguishing opportunities from ideas (Krueger, 1993:5; Krueger \& Brazeal, 1994:91; Krueger, 2000:5; Keh et al., 2002: 125), and (b) developing opportunities (Ardichvili et al., 2003:
113; Dimov, 2007:714). Due to the fact that the alternative hypotheses 1 and 2 were accepted (null hypotheses rejected), the conclusion is made that potential entrepreneurs assess opportunities through formulating a detailed business plan, as they could distinguish between ideas and opportunities and could develop opportunities.

Table 5 summarises the two null and alternative hypotheses in this study, the results indicated in the hypothesis testing above, as well as the significance level utilised.

Table 5

Summary of hypothesis testing

\begin{tabular}{|c|c|c|c|c|c|}
\hline \multirow{2}{*}{ Null hypotheses } & \multicolumn{2}{|c|}{ Inferential statistics } & \multirow{2}{*}{ Alternative hypotheses } & \multicolumn{2}{|c|}{ Inferential statistics } \\
\hline & $\alpha<0.05$ & $\alpha<0.1$ & & $\alpha<0.05$ & $\alpha<0.1$ \\
\hline $\begin{array}{l}\mathrm{H} 1_{\mathrm{o}} \text { : Potential entrepreneurs do not } \\
\text { distinguish between ideas and } \\
\text { opportunities through formulating } \\
\text { a detailed business plan. }\end{array}$ & Reject & & $\begin{aligned} \mathrm{H} 1_{\mathrm{a}} \text { : } & \text { Potential entrepreneurs } \\
& \text { distinguish between ideas and } \\
& \text { opportunities through formulating } \\
& \text { a detailed business plan. }\end{aligned}$ & Accept & \\
\hline $\begin{aligned} \mathrm{H} 2 \mathrm{o} & \text { Potential entrepreneurs do not } \\
& \text { develop opportunities through } \\
& \text { formulating a detailed business } \\
& \text { plan. }\end{aligned}$ & & Reject & $\begin{aligned} \mathrm{H} 2 \mathrm{a}: & \text { Potential entrepreneurs develop } \\
& \text { opportunities through formulating } \\
& \text { a detailed business plan. }\end{aligned}$ & & Accept \\
\hline
\end{tabular}

In reviewing the relationships built around the hypotheses, the study found strong support for hypotheses 1 and 2 . These hypotheses were composed of the relationships between the business plan (IV), and the DVs regarding opportunity assessment, which are summarised in figure 4.

Figure 4

Reviewing the relationship between the IVs and DVs

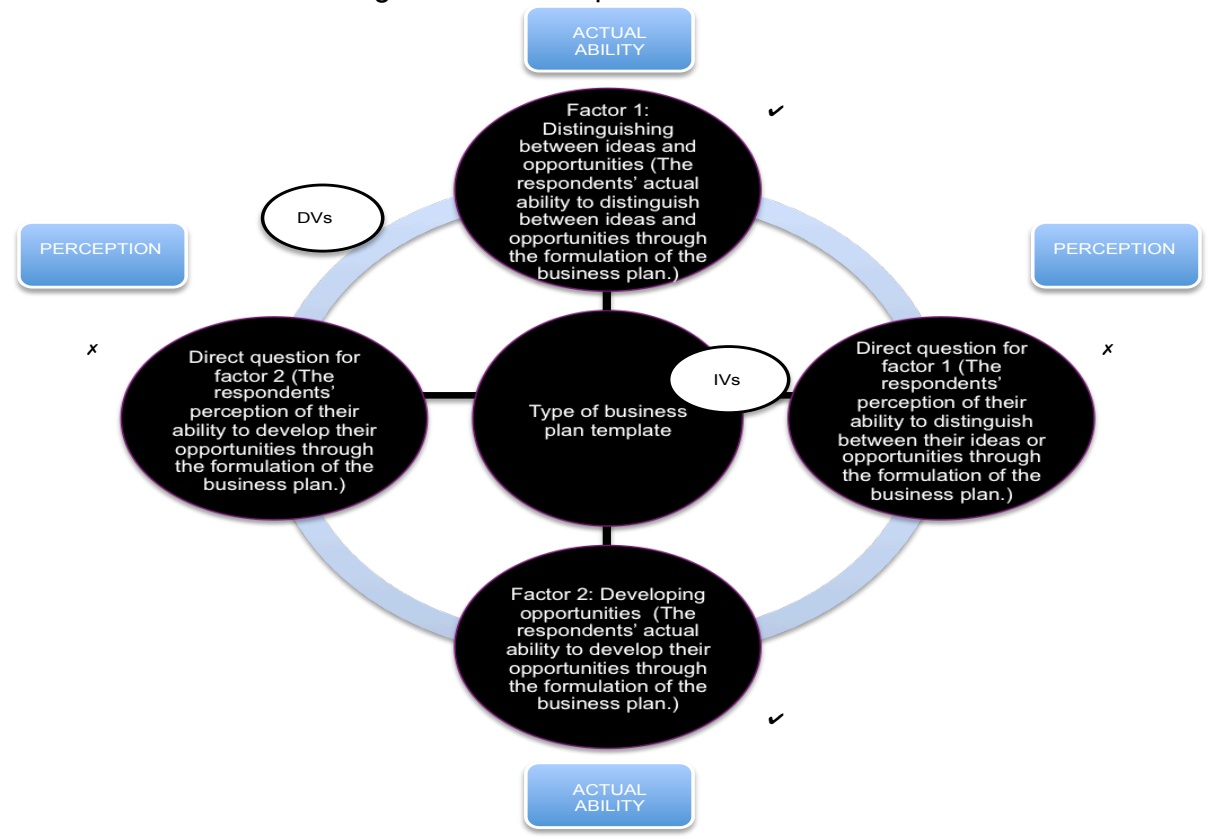


Crucially for the study, statistically significant differences were found between the respondents' actual ability to distinguish between ideas and opportunities and develop opportunities (factors measured) and the type of business plan used. Respondents who used a UP business plan, which is guaranteed to be detailed, stated they distinguished more strongly between ideas and opportunities, and respondents who used the UP business plan stated more strongly that they developed their opportunities. These are the results of the respondents answering questions strategically designed to test the ability of the respondents to assess opportunities. Very interestingly, when the respondents were asked the questions directly about their ability to assess opportunities, in order to gauge their perceptions, no statistically significant differences are found with regard to the type of business plan.

\section{5}

\section{Limitations of this study and areas for further research}

Although this study meets all applicable criteria for scientific validated research, the researcher must note some limitations encountered.

Questionnaires were sent out to 260 sample units, but the actual sample size is 76 , as 80 responses were successfully completed and returned while four respondents had to be excluded from the study, as they did not have business plans. Although 76 is still a satisfactory sample size, the planned sample size was 100 or more. However, due to time constraints, the study did not reach the planned sample figures. The sample size affects the confidence or faith attached to the results of the study (Welman, Kruger \& Mitchell, 2005:70) as well as the statistical significance of statistical tests.

The respondents were required to already have a business plan in order to complete the questionnaire. Thus, the formulation of their business plan was a past event. Information about past events is often available only through surveying or interviewing people who remember the events (Cooper \& Schindler, 2008:215). The study's questionnaire asked respondents to please answer honestly and accurately, but this researcher was aware of the differing time lapses between the respondents formulating their business plan and answering this questionnaire, which could cause slight distortion of actual events.

The most common levels of significance are 0.05 or 0.01 , which result in confidence levels of 95 per cent or 99 per cent, respectively. This study also used a 0.1 level of significance, which results in a confidence level of 90 per cent and is not infrequent in research but is not among those most commonly used. The reason for utilising this level of significance was that one of the results marginally missed the 0.05 level of significance and thus this step was taken to avoid Type II error as well as to avoid losing a significant finding.

This study proposes the following future research areas as a means to further validate and meaningfully expand this study:

- Repeat entrepreneurs (also known as serial entrepreneurs) were not included in this study as they could be expected to be different from first-time entrepreneurs. Experience is expected to influence assessing opportunities. Thus it would be interesting to extend this study to repeat entrepreneurs.

- Investigating the cognitive processes involved in formulating a business plan was beyond the scope of this study; however, they are a vital component in explaining why the formulation process aids opportunity assessment. Thus research in this area would be significant for further validation of this study.

- The question arises: if potential entrepreneurs assess opportunities through the formulation of a business plan, would this help potential entrepreneurs establish more viable business ventures? In order to investigate this, a longitudinal study would be required.

\section{6}

\section{Conclusion}

In a former study of leading entrepreneurship educators, the development of a business plan was identified as being the most important feature of entrepreneurship courses (Hills, 1988:109). However, the relevance of a business plan has been a topic of intense and unresolved debates in more recent literature. 
Thus this study analysed the relevant literature and hypothesised a future purpose of the business plan. Based on the tests conducted and the empirical results achieved, the null hypotheses (1 and 2) were rejected and the alternative hypotheses ( 1 and 2 ) were accepted. Thus, this study is significant as it proves that potential entrepreneurs distinguish between ideas and opportunities and, importantly, develop opportunities through the formulation of a detailed business plan. Therefore potential entrepreneurs assess opportunities through the formulation of a detailed business plan. The postulations are strongly supported theoretically and now the hypotheses are supported empirically.

The pertinent academic and practical significance of this study is that the study found statistically significant differences proving that a business plan is a tool that enables potential entrepreneurs to assess opportunities. Importantly, this study indicates that a detailed business plan is necessary for this purpose of assessing opportunities. Theoretically this should help potential entrepreneurs establish more viable business ventures; however, this would have to be statistically tested in further research. Finally, it re-establishes the importance or value of a business plan in the field of entrepreneurship.

\section{References}

ARDICHVILI, A., CARDOZO, R. \& RAY, S. 2003. A theory of entrepreneurial opportunity identification and development. Journal of Business Venturing, 18(1):105-123.

ASHAMALLA, M.H., ORIFE, J.N. \& ABEL, I. 2008. Business plans: are they relevant to venture capitalists? Journal of Small Business and Entrepreneurship, 21(4):381-392.

BARROW, C., BARROW, P. \& BROWN, R. 2001. The business plan workbook. (4th ed.) London: Kogan Page.

BISHOP, K. \& NIXON, R.D. 2006. Venture opportunity evaluations: comparisons between venture capitalists and inexperienced pre-nascent entrepreneurs. Journal of Developmental Entrepreneurship, 11(1):19-33. BOTHA, M. \& BOUWMEESTERS, A. 2006. The content and format of a business plan. Unpublished document. Pretoria: University of Pretoria.

BRINCKMANN, J., GRICHNIK, D. \& KAPSA, D. 2008. Should entrepreneurs plan or just storm the castle? A meta-analysis on contextual factors impacting the business planning-performance relationship in small firms. Journal of Business Venturing, doi:10.1016/j.jbusvent.2008.10.007 [1 -17].

COOPER, D.R. \& SCHINDLER, P.S. 2008. Business research methods. (10th ed.) Singapore: McGrawHill.

DELMAR, F. \& SHANE, S. 2003. Does business planning facilitate the development of new ventures? Strategic Management Journal, 24:1165-1185.

DIAMANTOPOULOS, A. \& SCHLEGELMILCH, B.B. 2000. Taking the fear out of data analysis. Singapore: Thompson.

DIMOV, D. 2007. Beyond the single-person, single-insight attribution in understanding entrepreneurial opportunities. Entrepreneurship Theory and Practice, 31:713-731, September.

FOO, M.D., WONG, P.K. \& ONG, A. 2005. Do others think you have a viable business idea? Team diversity and judges' evaluation of ideas in a business plan competition. Journal of Business Venturing, 20:385-402.

HILLS, G.E. 1988. Variations in university entrepreneurship education: an empirical study of an evolving field. Journal of Business Venturing, 3:109-122.

HILLS, G.E. \& SHRADER, R.C. 1998. Successful entrepreneurs' insights into opportunity recognition. In Reynolds, P.D., Bygrave, W.B., Carter, N.M., Manigart, S., Mason, C.M., Meyer, G.D. \& Shaver, K. G. (eds.) Frontiers of entrepreneurship research. Babson College, Babson Park, MA:30-43.

HISRICH, R.D., PETERS, M.P. \& SHEPHERD, D.A. 2008. Entrepreneurship. (7th ed.) Boston, MA: Irwin/ McGraw-Hill.

HONIG, B. 2004. Entrepreneurship education: toward a model of contingency based business planning. Academy of Management Learning and Education, 3(3):258-273.

HORMOZI, A., SUTTON, G., MCMINN, R. \& LUCIO, W. 2002. Business plans for new or small business: paving the path to success. Management Decision, 40(8):755-765. 
KARLSSON, T. \& HONIG, B. 2009. Judging a business by its cover: an institutional perspective on new ventures and the business plan. Journal of Business Venturing, 24:27-45.

KEH, H.T., FOO, M.D. \& LIM, B.C. 2002. Opportunity evaluation under risky conditions: the cognitive processes of entrepreneurs. Entrepreneurship Theory and Practice, 27(2):125-148, Winter.

KETCHEN, D.J., Jr. 2003. Entrepreneurship: past accomplishments and future challenges. Journal of Management, 29(3):281-283.

KICKUL, J., GUNDRY, L.K., BARBOSA, S.D. \& WHITCANACK, L. 2009. Intuition versus analysis? Testing differential models of cognitive style on entrepreneurial self-efficacy and the new venture creation process. Entrepreneurship Theory and Practice, 33(2):439-453, March.

KRUEGER, N.F. Jr. 1993. The impact of prior entrepreneurial exposure on perceptions of new venture feasibility and desirability. Entrepreneurship Theory and Practice, 18(1):5-21.

KRUEGER, N.F. Jr. 2000. The cognitive infrastructure of opportunity emergence. Entrepreneurship Theory and Practice, 24(3):523.

KRUEGER, N.F., JR. \& BRAZEAL, D.V. 1994. Entrepreneurial potential and potential entrepreneurs. Entrepreneurship Theory and Practice, 18(3):91-104.

LANGE, J.E., MOLlOV, A., PEARLMUTTER, M., SINGH, S. \& BYGRAVE, W.D. 2007. Pre-start-up formal business plans and post-start-up performance: a study of 116 new ventures. Venture Capital, 9(4):237256.

MCALLISTER, J.P. 1997. How to write a great business plan: editor review. Harvard Business Review, November-December:180-181.

MCMULLEN, J.S. 2011. Delineating the domain of development entrepreneurship: a market-based approach to facilitating inclusive economic growth. Entrepreneurship Theory and Practice,35(1):185215, January.

MORRISETTE, S. \& HATFIELD, L. 2010. Second-draft of a business plan: what should it contain? Journal of the International Academy for Case Studies, 16(I):115-132.

NIEMAN, G.H. \& NIEUWENHUIZEN, C. 2009. Entrepreneurship: a South African perspective. (2nd ed.) Pretoria: Van Schaik.

PRETORIUS, M. 2008. Assessment of entrepreneurship education: a pilot study. SAJESBM NS, 1(1):1-20.

ROBINSON, R. 1979. Forecasting and small business: a study of the strategic planning process. Journal of Small Business Management, 17:19-27.

SAHLMAN, W.A. 1997. How to write a great business plan. Harvard Business Review, July-August:98-108. SHANE, S. \& DELMAR, F. 2004. Planning for the market: business planning before marketing and the continuation of organizing efforts. Journal of Business Venturing, 19:767-785.

SINGH, R.P. 2001. A comment on developing the field of entrepreneurship through the study of opportunity recognition and exploitation. Academy of Management Review, 26(1):10-12.

SMELTZER, L.R., VAN HOOK, B.L. \& HUTT, R.W. 1991. Analysis of the use of advisors as information sources in venture start-ups. Journal of Small Business Management, July:10-20.

STEPHENSON, H., BROCK, M. \& LOUGHEAD, M. 2008. Urban outreach ministries' organic gardens: developing a sustainable, triple-bottom-line business for a nonprofit social enterprise. Journal of the International Academy for Case Studies, 14(8):69-78

STRUWIG. M. 2009. The business plan. In Nieman, G. \& Nieuwenhuizen, C. 2009. Entrepreneurship: a South African perspective. (2nd ed.) Pretoria: Van Schaik.

TIMMONS, J.A. \& SPINELLI, S. 2007. New venture creation: entrepreneurship for the 21st century. (7th ed.) Burr Ridge, IL: Irwin.

VENKATARAMAN, S. 1997. The distinctive domain of entrepreneurship research. Advances in Entrepreneurship, Firm Emergence and Growth, 3:119-138.

WALL, E. \& ENVICK, B.R. 2008. Business plan development for service ventures: integrating customer experience management. The Entrepreneurial Executive, 13:117-125.

WEBSTER, F. A. \& ELLIS, J. 1976. The very first business plan. Journal of Small Business Management, 14(1):46-50.

WELMAN, C., KRUGER, F. \& MITCHELL, B. 2005. Research methodology. (3 ${ }^{\text {rd }}$ ed.) Cape Town: Oxford University Press. 
WICKHAM, P.A. 2006. Strategic entrepreneurship: a decision-making approach to new venture creation and management. (4th ed.) London: Financial Times/Pitman.

WYCKHAM, R.G. \& WEDLEY, W.C. 1990. Factors related to venture feasibility analysis and business plan preparation. Journal of Small Business Management, 28(4):48-59.

\section{Appendix 1}

UP framework for business plan content and supporting authors

\begin{tabular}{|c|c|c|}
\hline $\begin{array}{l}\text { UP business plan } \\
\text { content }\end{array}$ & Content detail & Supporting authors \\
\hline Executive summary & Synopsis of all the subsequent sections ( 3 pages) & $\begin{array}{l}\text { Nieman \& Nieuwenhuizen (2009) } \\
\text { Stephenson, Brock \& Loughead (2008) } \\
\text { Timmons \& Spinelli, (2007) } \\
\text { Hisrich et al. (2008) }\end{array}$ \\
\hline Business description & $\begin{array}{l}\text { History; start date and basic nature / activities of } \\
\text { business, entrepreneurs and other people involved, } \\
\text { vision statement, mission statement, brand promise, } \\
\text { organisational values, sustainable competitive } \\
\text { advantage, form of ownership (legal implications), } \\
\text { achievements to date, objectives and Swot analysis. }\end{array}$ & $\begin{array}{l}\text { Wall \& Envick (2008) } \\
\text { Hisrich et al. (2008) } \\
\text { Timmons \& Spinelli (2007) } \\
\text { Wickham (2006) } \\
\text { Webster \& Ellis (1976) }\end{array}$ \\
\hline Products and services & $\begin{array}{l}\text { Range of products and services that will be offered; } \\
\text { costs / purpose / distribution of products, luxury } \\
\text { items / addresses weakness, creates opportunity, } \\
\text { value proposition of product/s, unique/ innovative } \\
\text { features over competitors; benefit to customers, } \\
\text { technology effects, the limitations or legal } \\
\text { implications, environmental implications and the } \\
\text { venture and product life cycle. }\end{array}$ & $\begin{array}{l}\text { Nieman \& Nieuwenhuizen (2009) } \\
\text { Stephenson, Brock \& Loughead (2008) } \\
\text { Hisrich et al. (2008) } \\
\text { Timmons \& Spinelli (2007) } \\
\text { Wickham (2006) } \\
\text { Foo et al. (2005) } \\
\text { Sahlman (1997) }\end{array}$ \\
\hline Industry analysis & $\begin{array}{l}\text { Primary industry characteristics, size and trends; } \\
\text { success factors to compete in industry, geographic } \\
\text { location and segmentation (target market of } \\
\text { industry), major role players in the industry; } \\
\text { competition, problems in the industry (also globally), } \\
\text { legislation influencing the industry, industry trends, } \\
\text { peak periods, seasonal trends and developments, is } \\
\text { the industry growing or declining?, profit } \\
\text { characteristics of the industry, intermediaries and } \\
\text { distribution channels; how they operate and their } \\
\text { costs. }\end{array}$ & $\begin{array}{l}\text { Hisrich et al. (2008) } \\
\text { Timmons \& Spinelli (2007) } \\
\text { Sahlman (1997) }\end{array}$ \\
\hline $\begin{array}{l}\text { Production, manufacturing } \\
\text { and operational plans }\end{array}$ & $\begin{array}{l}\text { Production of products, geographic location of } \\
\text { premises, factory facility, production strategy and } \\
\text { regulatory issues. }\end{array}$ & $\begin{array}{l}\text { Nieman \& Nieuwenhuizen (2009) } \\
\text { Wall \& Envick (2008) } \\
\text { Hisrich et al. (2008) } \\
\text { Timmons \& Spinelli (2007) } \\
\text { Webster \& Ellis (1976) }\end{array}$ \\
\hline Management team & $\begin{array}{l}\text { Management / organisational chart; and any } \\
\text { investors?, organisational structure; describe } \\
\text { structure / business units / subsidiaries, } \\
\text { management / owners' profiles, roles and } \\
\text { responsibilities; job description / duties, management } \\
\text { style, training; motivation for employees / trainer?, } \\
\text { supporting professionals; accountants / } \\
\text { transportation and additional staff for future. }\end{array}$ & $\begin{array}{l}\text { Nieman \& Nieuwenhuizen (2009) } \\
\text { Stephenson, Brock \& Loughead (2008) } \\
\text { Wall \& Envick (2008) } \\
\text { Wickham (2006) } \\
\text { Timmons \& Spinelli (2007) } \\
\text { Sahlman (1997) } \\
\text { Webster \& Ellis (1976) }\end{array}$ \\
\hline $\begin{array}{l}\text { Marketing research and } \\
\text { analysis }\end{array}$ & $\begin{array}{l}\text { The size and the maturity of the market; price } \\
\text { history, forecasts, seasonality, potential for growth, } \\
\text { trends, market research: market segmentation, } \\
\text { customers' demographic profile (target market), } \\
\text { competitive analysis and positioning maps, primary / } \\
\text { direct competitors, secondary / indirect competitors, } \\
\text { competitor analysis summary, future research; } \\
\text { possible developments and new markets. }\end{array}$ & $\begin{array}{l}\text { Brinckmann et al. (2008) } \\
\text { Timmons \& Spinelli (2007) } \\
\text { Wickham (2006) } \\
\text { Foo et al. (2005) }\end{array}$ \\
\hline Marketing plan & $\begin{array}{l}\text { Marketing and brand strategy, advertising and } \\
\text { product promotion, advertising media, target market, } \\
\text { product composition; packaging and labelling, } \\
\text { product pricing; guarantees and market penetration. }\end{array}$ & $\begin{array}{l}\text { Nieman \& Nieuwenhuizen (2009) } \\
\text { Stephenson, Brock \& Loughead (2008) } \\
\text { Wall \& Envick (2008) } \\
\text { Hisrich et al. (2008) } \\
\text { Timmons \& Spinelli (2007) }\end{array}$ \\
\hline
\end{tabular}




\begin{tabular}{|c|c|c|}
\hline $\begin{array}{l}\text { UP business plan } \\
\text { content }\end{array}$ & Content detail & Supporting authors \\
\hline Economics of the business & $\begin{array}{l}\text { Break-even analysis; show fixed / variable costs, } \\
\text { time to positive cash flow, and costs. }\end{array}$ & $\begin{array}{l}\text { Hisrich et al. (2008) } \\
\text { Timmons \& Spinelli (2007) } \\
\text { Foo et al. (2005) } \\
\text { Sahlman (1997) } \\
\text { Webster \& Ellis (1976) }\end{array}$ \\
\hline Financial plan & $\begin{array}{l}\text { Financial management; historical financial data, } \\
\text { income statement projections for three years, } \\
\text { balance sheet projections for three years, cash flow } \\
\text { projections for three years. }\end{array}$ & $\begin{array}{l}\text { Nieman \& Nieuwenhuizen (2009) } \\
\text { Stephenson, Brock \& Loughead (2008) } \\
\text { Wall \& Envick (2008) } \\
\text { Hisrich et al. (2008) } \\
\text { Timmons \& Spinelli (2007) } \\
\text { Wickham (2006) } \\
\text { Mcallister (1997) } \\
\text { Webster \& Ellis (1976) }\end{array}$ \\
\hline Design and development & $\begin{array}{l}\text { Development status and tasks; admin policies, } \\
\text { procedures, controls, difficulty and risk concerning } \\
\text { design and development. }\end{array}$ & Timmons \& Spinelli (2007) \\
\hline Growth plan & $\begin{array}{l}\text { A growth plan for five years and new products for the } \\
\text { future. }\end{array}$ & Timmons \& Spinelli (2007) \\
\hline Action plan & A detailed action plan for 12 months. & $\begin{array}{l}\text { Timmons \& Spinelli (2007) } \\
\text { Wickham (2006) } \\
\text { Robinson (1979) }\end{array}$ \\
\hline $\begin{array}{l}\text { Critical risks, problems and } \\
\text { assumptions }\end{array}$ & $\begin{array}{l}\text { Major problems and risks, 'what ifs' followed by } \\
\text { contingency plans, environmental impact. }\end{array}$ & $\begin{array}{l}\text { Hisrich et al. (2008) } \\
\text { Timmons \& Spinelli (2007) } \\
\text { Sahlman (1997) }\end{array}$ \\
\hline $\begin{array}{l}\text { Proposed offering (Desired } \\
\text { finance) }\end{array}$ & $\begin{array}{l}\text { Show how you are going to spend the funding, } \\
\text { investors' return and security. }\end{array}$ & Timmons \& Spinelli (2007) \\
\hline
\end{tabular}

\section{Appendix 2}

Factor analysis conducted on the first set of variables Sorted rotated factor loadings (pattern)

Factor: Distinguishing between ideas and opportunities

The business plan helped me decide if my idea was commercially viable (could be sold).

The business plan helped me decide if there was a market demand for my product.

The business plan helped me decide if my idea was actually a business opportunity.

The business plan helped me decide whether my product/service has value to my potential target market.

The business plan helped me decide if a potential target market exists for my product/service.

The business plan helped me decide if my business idea was potentially feasible (profitable).

The business plan helped me decide if I had the right resources available to start my business.

The business plan helped me decide if my idea needed to change in order for it to be a feasible business opportunity.

The business plan helped me decide whether I wanted my idea to become a business.

Factor analysis conducted on the second set of variables

\begin{tabular}{|l|c|}
\hline \multicolumn{1}{|c|}{ Sorted rotated factor loadings (pattern) } \\
\hline \multicolumn{1}{|c|}{ Factor: Developing opportunities } \\
\hline The business plan helped me improve my business idea to become a valid business opportunity. & 0.783 \\
\hline I learnt a lot about how my business would operate in its environment. & 0.764 \\
\hline The business plan helped me realise that there were gaps in my business idea. & 0.697 \\
\hline I added things to my business idea that I had initially not thought about. & 0.666 \\
\hline $\begin{array}{l}\text { I realised I had to reconsider aspects of my business idea, otherwise my initial idea would not have been } \\
\text { successful. }\end{array}$ & 0.664 \\
\hline I modified or adjusted my business idea. & 0.634 \\
\hline I improved my product/service. & 0.612 \\
\hline The business plan helped me realise that I had not considered everything about my business idea. & 0.455 \\
\hline I did market research. & 0.310 \\
\hline
\end{tabular}

